\title{
Project Practitioners' Competency in Malaysian Construction Industry
}

\author{
Noor'Ain Zainal Abidin ${ }^{\mathrm{a}}$, Mohamad Syazli Fathia ${ }^{*}$, Mohd Yusof Md Dauda, Harmi Izzuan Baharum ${ }^{\mathrm{b}}$ \\ aUTM Razak School of Engineering and Advanced Technology, Universiti Teknologi Malaysia, 54100 Kuala Lumpur, Malaysia \\ ${ }^{b}$ UTM Language Academy, Universiti Teknologi Malaysia, 54100 Kuala Lumpur, Malaysia \\ *Corresponding author: syazli@utm.my
}

\begin{abstract}
The purpose of this study is to investigate which competencies are perceived importance by the project practitioners in order for them to perform accordingly towards achieving project objectives. At the same time, the study also allows the opportunity to evaluate their keenness on self-learning which is important for project practitioners to continuously enhancing their skills. Questionnaires are distributed at one of Malaysian Government Department, which is responsible for the construction of government infrastructure projects in the country. Total of 179 respondents gave their feedbacks during a training, a workshop and talk events. Six (6) types of competencies were measured. The findings indicate that three most important competencies perceived by project practitioners are Behavioral, Technical Generic and Generic competencies. On top of that, feedbacks on self learning elements shows that the project practitioners are agreeable and aware on the importance of learning and are willing to take up their own time to learn by themselves. This study revealed the behavioral competency is the most importance competency perceived by the project practitioners. With this information, the Department could plan the project practitioners' development programs more effectively and drive the motivation to learn continuously. Effective learning creates skilled human resources who could withstand the competitive environment in the construction industry.
\end{abstract}

Keywords: Project success; competency; learning; construction

(C) 2017 Penerbit UTM Press. All rights reserved

\subsection{INTRODUCTION}

Construction industry is one of the sectors that contributed to the nation development. Its significant impact is mainly seen in the area of socioeconomic infrastructure, e.g. schools, roads, hospitals and bridges (Hussin, Rahman et al. 2013). Each year, the Government of Malaysia allocated a sum of money for its development activities. For example, the development budget for year 2013 was RM 477 billion (Finance 2013). Out of this amount, 5,985 projects were planned, which has the value of RM 92.3 billion (CIDB 2014). In order for Malaysia to become a progressive nation by year 2020, a strong economic expansion is required. Hence, successful project implementation will affect the infrastructure development for the nation.

Construction industry also gives impact to the employment opportunities in this nation. According to Ministry of Finance's Economic Report 2013/2014 (Finance 2014), the number of registered workers involved in the construction industry was about 1.23 million, which contribute to $9.4 \%$ of the total workforce in Malaysia. There is an increase in worker employment for year 2013 as much as $0.3 \%$ compare to 2012. This indicates that construction industry provides ample employment to the people which lead to the increase in quality of life (Olanrewaju and Abdul-Aziz 2015).

Construction of building and infrastructure projects entail long term investment and long term risks. Therefore, the projects implemented must be proper planned and managed carefully in order to be successful. Malaysian construction industry is said to be under achieving (Yong and Mustaffa 2012), whereby project success is one of the issues or challenges in project implementation. In general, unsuccessful projects are those which did not meet the time, cost and quality specified by the client. Poor project management performance is not just happening domestically but happen in the other part of the world as well. A project management survey conducted by KPMG in New Zealand for the year 2012 revealed that only 33\% projects delivered on budget, $29 \%$ delivered on time and 35\% delivered the stated deliverables (Barlow, Woolley et al. 2013). In 2015, KPMG did a global construction survey that covered Americas, Asia Pacific, Europe, Middle East and Africa regions(Armstrong 2015). The findings show that $47 \%$ of the projects in that year were underperforming. Only $31 \%$ of the projects meeting more than $90 \%$ planned budget.

Construction industry nowadays is unpredictable and dynamic in nature. The development of information and communication technologies (ICT) has significantly influenced the way projects are being managed. A good example is the introduction of Building Information Modelling (BIM). BIM has assisted designer to create complex building design and also used to show how building is constructed from learning perspective (Becerik-Gerber, Ku et al. 2012). In view of this condition, it is essential for those who involved in project, i.e. the project practitioners, have the right competencies. A project and program management survey conducted in Sweden (Braun 2015) discovered that three (3) main factors that contributing to project success were: 1) solid project management and skill to manage projects; (2) project scope meeting client expectation; and (3) well project resource allocation process.

The study is to answer the question on which competencies that are importantly perceived by the project practitioners. The results of this study will facilitate the Department in identifying the right training and development programs required by project practitioners. In the 
long run, the Department will attain competent individuals and a value added investment from training. In addition to that, it is important for the individuals to have a continuous learning in order to maintain or enhance their skills and keep abreast of new technologies.

This paper begins by looking who is involved in project and the competency needed by the project manager. Following this, the methodology used is demonstrated and findings are presented. Next, the discussion is stated and finally, conclusion is made.

\subsection{LITERATURE REVIEW}

Past studies revealed that some form of project management has been applied in projects since thousands of years ago. Looking at great buildings or structures like the Giza Pyramid, the Colosseum and the Taj Mahal, one has to believe that an approach was used to deliver the project in an organized way (Berkun 2008, Singh 2015). According to (Kwak 2005), there were four (4) unique spans of project management as follow:

Table 1 Four spans of project management

\begin{tabular}{|c|l|l|}
\hline Spans & \multicolumn{1}{|c|}{ Themes } & \multicolumn{1}{c|}{ Sub-context } \\
\hline Prior to 1958 & Craft system to Human Relations Administration & $\bullet$ \\
\hline $1958-1979$ & Application of Management Science & Project Management \\
Actual Projects
\end{tabular}

An observation was made on project management practices between the year 1960s up to 1990s. It is noted that during this span, people were focusing on tools and systems which could aid them in managing projects. The emphasis on people side of project management was only taken into consideration in the $21^{\text {st }}$ century (Weaver 2007). Project management competencies as tabulated in Table 1 were only determined after the project management association establish guideline on project management practices. The first project management association was set up in Europe in 1967 which is known as International Project Management Association (IPMA). Two year later, Project Management Institute (PMI) was formed in United States of America (USA) (Singh 2015).

\section{Project Success}

A project is a series of activities to be completed in a specified time to create a unique product (Kerzner 2009). In order for the project to be implemented, resources are required to perform the activities. There are four (4) main resources, i.e. man power, money, machines and materials (P 2015). Project manager is one of the key man powers who is responsible throughout the project life cycle to ensure the project implemented is in accordance to the specified time, cost, quality and meets client expectations (McHenry 2008). As ambiguity could emerge any time at any phase of the project implementation, project manager need to apply his/her skills using the best practices in project management to deal with the problem before it is elevated and become a crisis. Henceforth, it is vital for project manager to have the specific competencies to oversee the project.

The emphasis on project management competencies is further given much attention when past studies have shown findings that competency is a factor that affects the project success. Project success could be defined as primary fields of activity in which favorable outcomes are completely essential for a project manager to achieve his/her goals (Rockart and Sloan 1982). Identification of critical success factors based on previous studies could be seen in Table 2.

As can be seen in Table 2, it is important to realize that project practitioners, especially the project manager, must have the competencies to ensure project success.

\section{Project Management Competency}

Definition of competency given by the International Project Management Association (IPMA), is a consolidation of knowledge, skill and attitude (IPMA 2006). IPMA Competence Baseline for Project Management listed down three (3) main competencies based on project managers' perspectives, i.e. technical, behavioral and contextual. Technical competencies consist of twenty (20) elements which are related to project management substances on the handled project. Behavioral competencies have fifteen (15) elements which contribute to the personal relationships between the project manager and the stakeholders. Contextual competencies comprise of eleven (11) elements in regard to the synergy of the project team within the formation of the project and with the main organization. Those who want to be certified as professional in projects by IPMA, will be evaluated using these companies.

Many organizations conducted studies to identify what are the competencies required by their project practitioners, especially the project manager. Using classification of competencies given by IPMA, the finding of some studies are tabulated as seen in Table 3.

From Table 3, it could be concluded that the competencies required by project practitioners differ from one industry to another. Nevertheless, there are common competencies which applicable to each industry. Once the competencies are determined, the training and development program will be easier to strategize and implement in order to meet the organization's goals and missions. 
Table 2 Critical success factors

\begin{tabular}{|c|c|c|}
\hline Period & Critical Success Factors & Sources \\
\hline \multirow[t]{2}{*}{$1970 \mathrm{~s}$} & $\begin{array}{l}\text { Project manager competence, scheduling, control system and responsibilities, communication, } \\
\text { monitoring and feedback, continuous involvement in project }\end{array}$ & (Chandler and Sayles 1971) \\
\hline & $\begin{array}{l}\text { Top management support, financial support, logistic requirements, facility support, project schedule, } \\
\text { executive development and training of personnel, resources, information and communication } \\
\text { channels }\end{array}$ & (Cleland and King 1975) \\
\hline \multirow[t]{2}{*}{$1980 \mathrm{~s}$} & $\begin{array}{l}\text { Clear goals, on-site project manager, goal commitment of project team, adequate funding, adequate } \\
\text { project team capability, planning and control techniques, absence of bureaucracy }\end{array}$ & (Baker, Murphy et al. 1988) \\
\hline & $\begin{array}{l}\text { Project mission, top management support, project schedule, client consultation, personnel hiring and } \\
\text { development, client acceptance, technical tasks, monitoring and feedback, communication, trouble } \\
\text { shooting }\end{array}$ & (Pinto and Selvin 1987) \\
\hline \multirow[t]{2}{*}{$1990 \mathrm{~s}$} & $\begin{array}{l}\text { Planning and control techniques, team chemistry, team commitment, team work among all project } \\
\text { stakeholder, risk and reward contract, competence team, information and communication channels }\end{array}$ & (Sanvido, Grobler et al. 1992) \\
\hline & $\begin{array}{l}\text { Project manager and project team competence, project manager and project team commitment, } \\
\text { urgency of the project, top management support, project organizational structure, client consultation } \\
\text { and acceptance, external environment (political, social, economic, technological) }\end{array}$ & (Belassi and Tukel 1996) \\
\hline \multirow[t]{4}{*}{$21^{\text {st }}$ century } & $\begin{array}{l}\text { Competent project manager, adequate funding, multidisciplinary and competent project team, } \\
\text { project commitment, availability of resources }\end{array}$ & (Nguyen, Ogunlana et al. 2004) \\
\hline & $\begin{array}{l}\text { Client financial capability, monitoring and feedback, multidisciplinary and competent project } \\
\text { stakeholders, team work among project stakeholders, project commitment, information and } \\
\text { communication channels, effective allocation of manpower }\end{array}$ & (Yong and Mustaffa 2012) \\
\hline & $\begin{array}{l}\text { Cooperation/collaboration/consultation/communication among stakeholders, time, clear objectives, } \\
\text { client acceptance, cost, project manager competence, top management support, project commitment }\end{array}$ & (Davis 2014) \\
\hline & $\begin{array}{l}\text { Project organization, project manager competence, project risk management, project team } \\
\text { competence, requirements management, top management support, contractual aspects, institutional } \\
\text { factors, external challenge, client knowledge and skill, project characteristics }\end{array}$ & (Tsiga, Emes et al. 2016) \\
\hline
\end{tabular}

Table 3 Identification of competencies based from previous studies

\begin{tabular}{|c|c|c|c|c|}
\hline \multirow[t]{2}{*}{ Industry } & \multicolumn{3}{|c|}{ Type of Competencies } & \multirow[t]{2}{*}{ Sources } \\
\hline & Technical & Behavioral & Contextual & \\
\hline $\begin{array}{l}\text { Engineering } \\
\text { company }\end{array}$ & $\begin{array}{l}\text { Project management processes } \\
\text { Technical }\end{array}$ & Personal & Context and business & (Takey and Carvalho 2015) \\
\hline $\begin{array}{l}\text { Non-governmental } \\
\text { organization }\end{array}$ & $\begin{array}{l}\text { Communication } \\
\text { Networking and local knowledge }\end{array}$ & $\begin{array}{l}\text { Adaptability } \\
\text { Spans of abilities } \\
\text { Personal qualities } \\
\text { Interpersonal skills } \\
\text { Leadership } \\
\text { Ethics } \\
\text { Change management }\end{array}$ & $\begin{array}{l}\text { Management skills } \\
\text { Capacity building }\end{array}$ & (Brière, Proulx et al. 2015) \\
\hline Public sector & Technical & Behavioral & Contextual & (Jałocha, Krane et al. 2014) \\
\hline $\begin{array}{l}\text { Consultation } \\
\text { company }\end{array}$ & Knowledge/Cognitive & $\begin{array}{l}\text { Personal/Behavior } \\
\text { Values/Ethical }\end{array}$ & Functional & $\begin{array}{l}\text { (Mahmood, Hamidaddin et } \\
\text { al. 2006) }\end{array}$ \\
\hline
\end{tabular}

\section{Learning}

Simple definition of learning given by Oxford Living Dictionaries is the obtaining of knowledge or skill by virtue of study, experience or being taught (Oxford 2016). In order to instill the knowledge and skill to the employees, the Department provides training and learning opportunities at workplace via various methods and media. According to (Jacobs 2010), training and learning at workplace could be divided into four (4) quadrant as Figure 1.

Location of the training

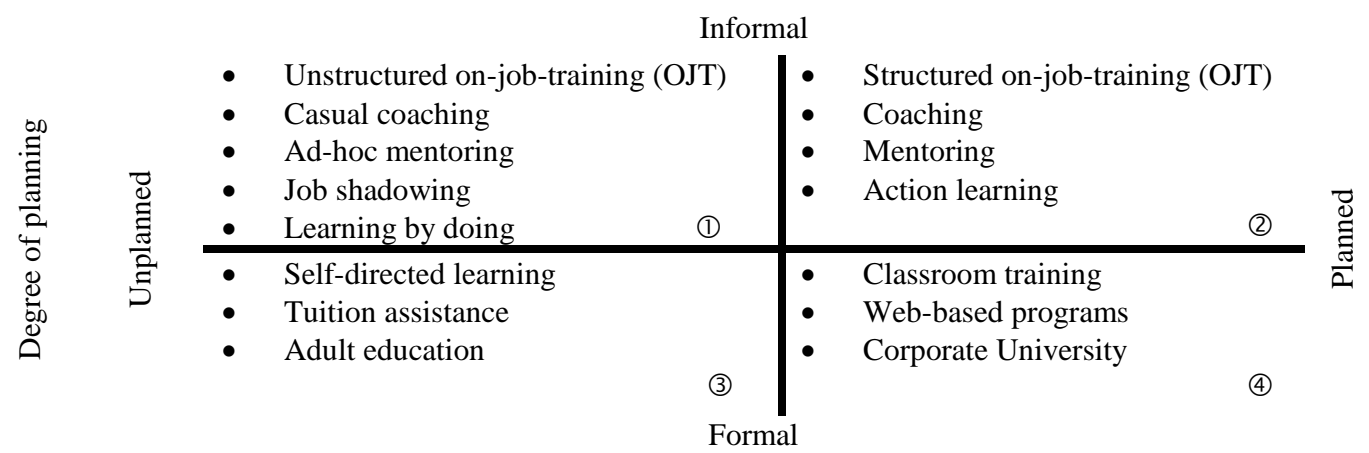

Figure 1 Training and learning at workplace 
Quadrant 2 and 4 represent training and learning which are usually provided by the organization. Classroom training is the most common training method conducted by the organization. It gives face-to-face interaction with the trainer, group interaction with other participants, similar information is disseminated at the same time and it is cost effective, if using internal human resource (BLR 2016, BLR 2016). Even though this training method is the efficient method to deliver idea whether to small or big groups, it could only be organized for limited number each year and it is dependent on the organization's financial capability that year. An analysis on workplace learning by (Tauber, Smolen et al. 2016) demonstrated that classroom trainings are done quarterly. Figure 2 illustrates the full analysis.

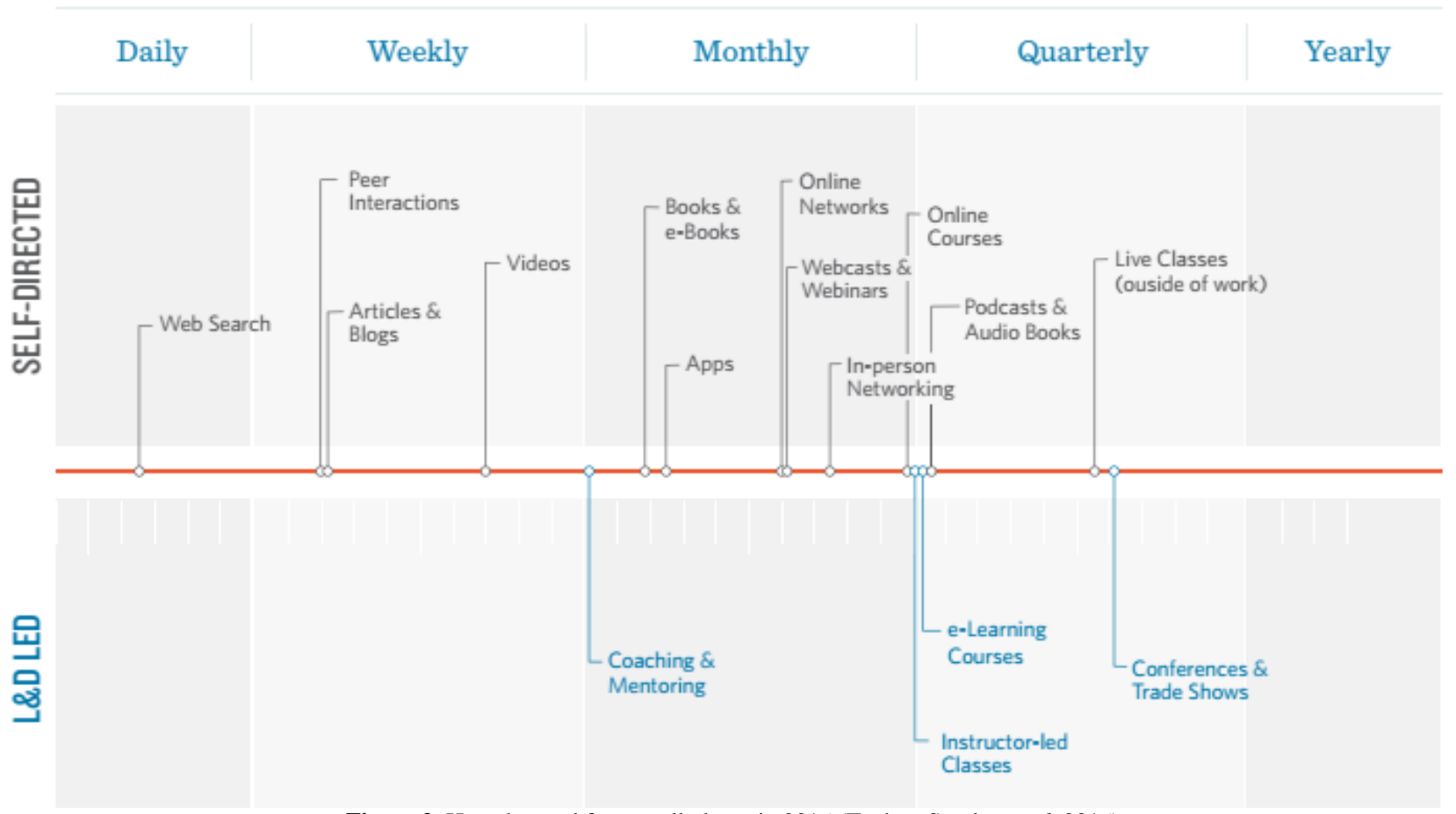

Figure 2 How the workforce really learn in 2016 (Tauber, Smolen et al. 2016)

These findings suggest that an organization could only provide limited time for its employee development. In addition to this, the employees raise up issues on classroom training which are not giving sufficient guidance or direction and lack of recognition from the learning they have acquired. Therefore, in order for the employees (in this study, referring to project practitioners) to maintain or enhance his or her competency, he or she need to learn by themselves, on top of learning activities provided by the organization. Prior studies show that the term self learning is also known as self-regulated learning (Steffens 2015) or self-directed learning (Ahmad and Majid 2010). Whichever the term is used, self-learning is about learners taking their own initiatives to gain knowledge or skill, with or without assistance of others, by means appropriate to them. Since self learning is a learner centered learning process, the learner has to have a motivation to drive them towards continuous development of oneself (Malik and Danish 2010). Employees with improved competency will perform better in executing their tasks. This is important, if the organization want to remain competitive.

\subsection{METHODOLOGY}

\section{Research Design}

The present study employ survey research to gather information on project practitioners' perspectives towards type of competencies and self-learning. The benefits of using survey research are the data obtained is from real-world observation and large amount of data could be achieved in shorter time at lower cost (Kelley, Clark et al. 2003). There are many forms of survey research, i.e. interviews (face-to-face or by telephone), questionnaires (paper or online) or the combination any of these methods. Using paper questionnaires, the perceived important competencies is identified and the motivation level is analyzed. The questionnaires were given to the respondents during several occasions, i.e. a training, a workshop and talk sessions.

\section{Research Instrument and Participants}

The questionnaires were self-administered and distributed at one of Malaysia Government Department, whereby the Department is responsible for all government infrastructure projects and the maintenance of government infrastructure assets throughout Malaysia. The Department's scopes of services cover technical consultation, project management and asset management. Even though the survey was conducted in Kuala Lumpur, the respondents also include those who work outside Kuala Lumpur.

The objectives of the survey are to obtain respondents' perspectives on competencies importance to them and their perspectives on self-learning. The questions on competencies are based on the Department's Competency Model and Dictionary. There are six (6) main competencies identified in this Competency Model and Dictionary, i.e. Behavioral, Functional, Generic, ICT and Language, Technical 
Generic and Technical competencies. Each competency contains several questions related to the competency. With respect to respondents' perception towards self learning, ten (10) questions have been designed.

Likert Scale is assigned to each question in order to determine the project practitioners' point of views in relation to project management competencies and self-learning. Likert Scale is used because according to Rensis Likert, an individual will respond similarly towards any given matter, along negative-to-positive dimension (Johns 2010). The scales for competency ranging from 1 to 5, where 1 refers to 'not importance' and 5 as 'most importance'. Whereas, the scales for self-learning indicate 1 as 'strongly disagree' and number 5 representing 'strongly agree'.

\subsection{FINDINGS}

\section{Respondents' Profile}

Simple statistical analysis was used to describe the respondents' background. The findings are as follow:

Referring to Figure 3, most of the feedbacks received are from female respondents.

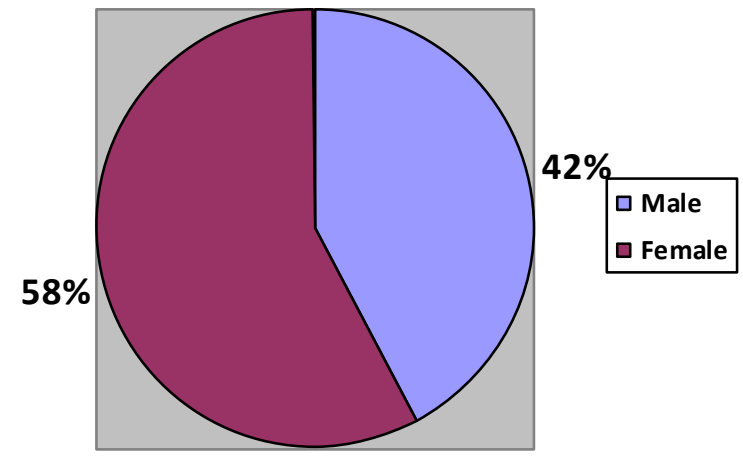

Figure 3 The percentage of gender in the survey

In Figure 4, it is clear that respondents categorized as 'Generation X' (age range of $32-49$ years old) contributed more to the survey.

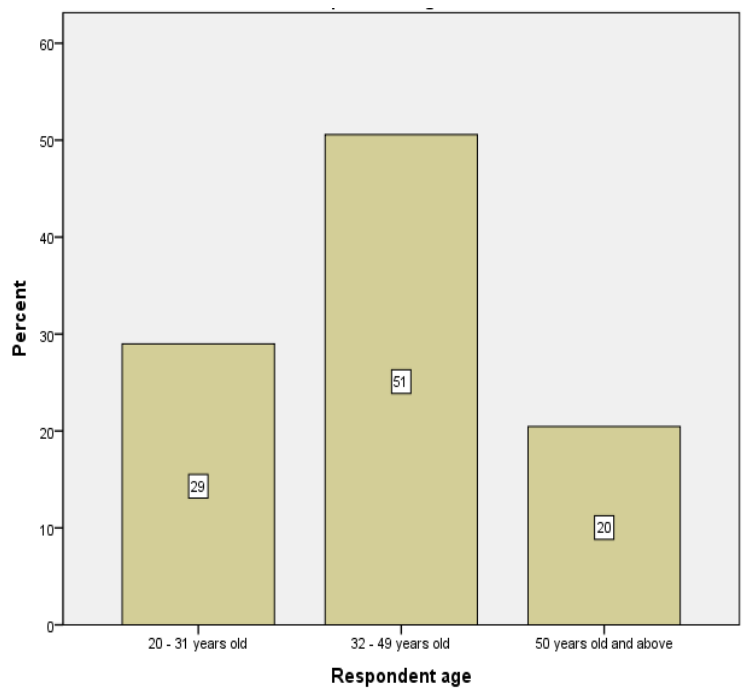

Figure 4 Percentage of respondents according to age range

Out of 179 respondents, $73 \%$ of them have a civil engineering background. This is clearly shown in Figure 5. 


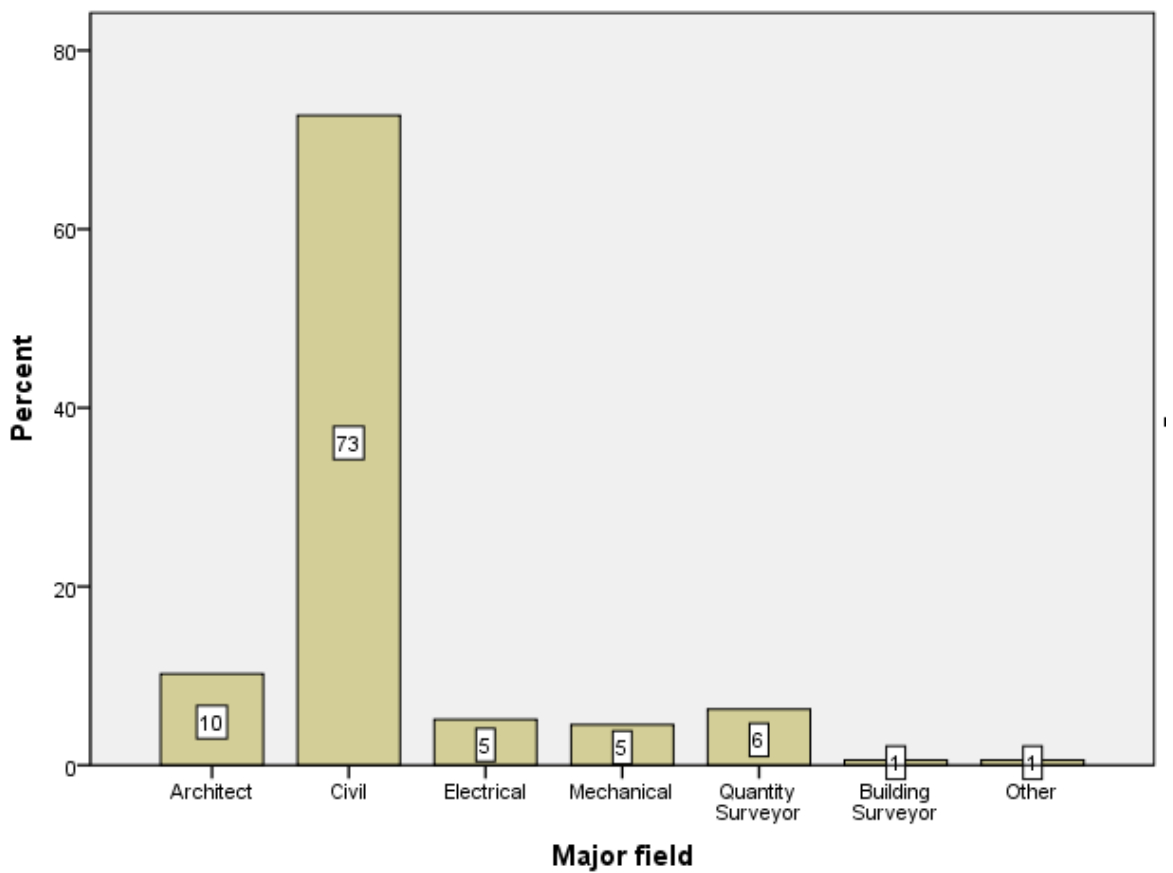

Figure 5 Percentage of respondents' field area

\section{Competencies}

The set of questions in relation to competencies comprises of:

- Behavioral (six questions);

- $\quad$ Functional (four questions);

- Generic (five questions);

- Information, Communication and Technology (ICT) and Language (3 questions);

- Technical Generic (six questions); and

- Technical (five questions).

A reliability analysis has been carried out to establish that the measurement scale used is reliable in obtaining all the responses. The analysis is based on the Cronbach's alpha value. With reference to (Santos 1999), the scale has internal consistency and reliability, when the value of Cronbach's alpha is more than 0.70 . The calculated value for competencies questions is 0.956 .

The mean scores for each competency are measured to identify the most importance competencies perceived by project practitioners. The result is presented as in Figure 6.

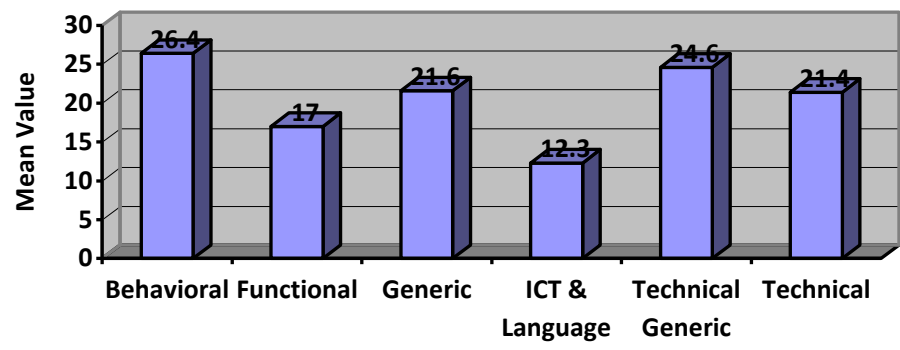

Category of Competencies

Figure 6 Mean value for each competency

It is apparent that the most important competencies perceived by project practitioners could be ranked as below:

1. Behavioral

2. Technical Generic

3. Generic

4. Technical

5. Functional

6. ICT \& Language 
According to the Department Competency Model and Dictionary, Behavioral Competencies comprises of elements or value that inspire outstanding work performance within the Department. Employees with these values not only knowledgeable in their technical skill but also have good relationship with others and could influence and lead the team successfully. Whereas, Technical Generic Competencies include distinctive competency required in project management, for example project management best practices. Generic Competencies are general values related to people management, e.g. communication.

\section{Self Learning}

There are ten questions with regards to self-learning. The questions are:

1. I am motivated in improving existing knowledge \& skill

2. I am aware on the required competency to perform tasks

3. I am aware and understand department training policy

4. I am applying course/training related to the job

5. I am interested in attending courses/training organized internally

6. I am interested in attending courses/training organized externally

7. I am taking time to study on my own using internet medium

8. I believe that searching for knowledge will assist in improving my expertise

9. I have ICT skills to obtain information on courses/training related to own field

10. I am confident with my existing skills to interact/contribute in any projects involved

The Cronbach's alpha for the set of question above is calculated and value of 0.869 . Just like competencies, the value is also more than 0.70 . Henceforth, the scale used is reliable. Using descriptive analysis, the percentage of respondents' view is calculated and it is based on these three scales:

\begin{tabular}{ll} 
Disagree & Those who give 1 and 2 marks \\
\hline Neutral & Those who give 3 marks \\
\hline Agree & Those who give 4 and 5 marks \\
\hline
\end{tabular}

The total result as presented in Figure 7.

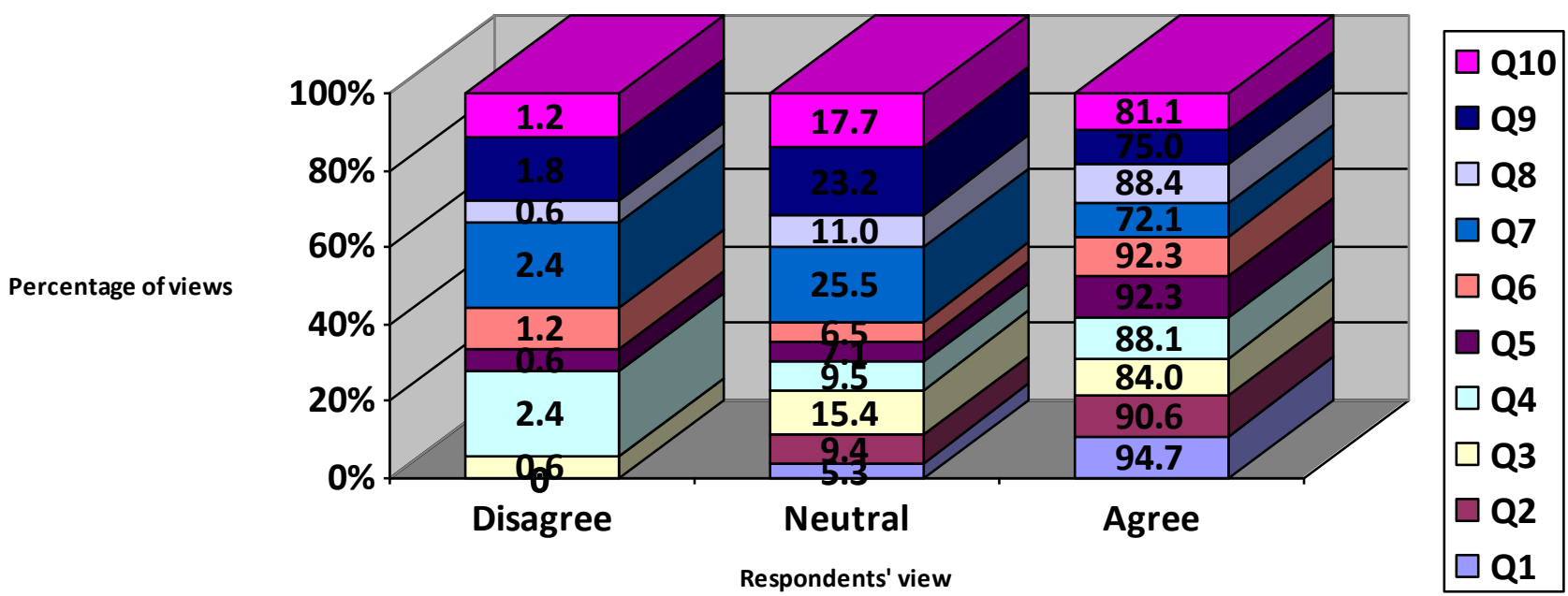

Figure 7 Respondents' views on self-learning

The most striking result to emerge from the analysis is that almost $95 \%$ of project practitioners have the drive to improve their existing knowledge and skill. They are aware on the importance to develop themselves and continue learning. The drive is supported by the view on the need to search knowledge to improve existing skill, which was $84 \%$ agreed by them. Equally important, about $92 \%$ of them are keen to attend training whether it is organized by the Department or outside organization.

\subsection{DISCUSSION}

Vision 2020, which is a vision inspired by the former prime minister Tun Mahathir Mohamad, envisages to change Malaysia into a prosperous, competitive, dynamic, robust and resilient nation by that time (Khan, Liew et al. 2014). Construction industry play a significant role in nation economic development. Construction industry contributes to the nation gross domestic product (GDP) after services, manufacturing, mining and quarrying, and agriculture industries in 2013 (Olanrewaju and Abdul-Aziz 2015). The Department of Statistics, Malaysia reported that for the third quarter of 2016, construction industry GDP rate has increase as much as $7.9 \%$ which is higher compare to services and manufacturing industries (Malaysia 2016). Henceforth, construction industry is a very important and productive industry that only affected the nation economy but also in making and enhancing the comforts or quality of living required by 
the people. The most obvious example of the effect of construction industry is the implementation of Mass Rapid Transit (MRT) project. The construction of MRT is to ease public movement and to give efficient urban transportation in connecting people from sub-urban areas to the city center.

The Department in concerned is significantly involved in government infrastructure projects. Therefore, the Department has a big responsibility to ensure the projects are managed and implemented efficiently and successfully. The Department's biggest asset is its human resource who involved in the projects along the project life cycle. Those employees involved, i.e. the project practitioners, must have the competency to carry out these responsibilities. Looking at the need of having the right competency, the Department developed its own Competency Model and Dictionary.

The findings show that, the rank of competencies perceived importance by the project practitioners are: Behavioral, Technical Generic, Generic, Technical, Functional, and ICT and language. Behavioral Competencies is the utmost importance competencies. Among the values required for Behavioral Competencies are 'Impact and Influence' and 'Visionary Leadership'. These values are crucial for a project manager. In order to ensure project is successfully managed, the project manager requires the expertise of personnel from various departments. The project manager must know how to influence the personnel and use their expertise to achieve project objectives (Gillard 2009). Besides that, the project manager must also lead the project on day-to-day basic and give morale support to the project team in term of work and/or personal development. Furthermore, there are other project stakeholders who are not inside the Department that the project manager need to deal with throughout project implementation. This situation requires the project manager to have strong organizational and people skills which are part of Behavioral Competencies. According to the findings, the Department are required to focus on the development related to these competencies.

It is also important for the Department to look at project manager development which is related to Technical Generic Competencies. Project management best practices give guidance to project manager the systematic to oversee a project. For this reason, project manager must keep abreast with the latest practices and any emerging new technology which will enhance project activities. Consequently, the Department could strategize its personnel development program effectively. The result will be efficient and competence project practitioners.

This study has raised important issues on the competencies that need to be acquired by project practitioners. Existing personnel development provided by the Department alone, could not cover all the competencies required, as there are limited time and space for training (Tauber, Smolen et al. 2016). There is also a risk that the development program could not be conducted due to insufficient budget. Notwithstanding these conditions, the learning processes have to be continued. The project practitioners need to realize the important of learning and self-learning is required to back up the existing development program conducted by the Department. The results of this study indicates that not only the respondents are aware of the need to search for knowledge, but they are also driven towards learning. They are willing to sacrifice their own time to search for new knowledge and improve existing skill. The urge to keep improving from time to time requires continuous learning. For this reason, the Department should investigate further on the effectiveness of its development program and evaluate whether existing learning approach could be improving or alternative learning approach need to be provided.

\subsection{CONCLUSION}

Overall, this study strengthens the idea that project management competencies are important to project practitioners and need to be developed from time to time. With the right competencies, the Department will able to be competitive in construction industry. This study also raised the important questions on which categories of competencies should be focused by the Department in order to optimize and effectively conduct project practitioners' development program. Another conclusion that can be drawn from this study is for the Department to motivate its project practitioners to continuously enhance competency through self learning. Further studies regarding the effectiveness of existing learning approaches would be recommended to further improve project practitioners' development program.

\section{References}

Ahmad, B. E. and Majid, F. A. (2010). Self-directed Learning and Culture: A Study on Malay Adult Learners. Procedia - Social and Behavioral Sciences, 7, 254-263. Armstrong, G. (2015). Global Construction Survey 2015: Climbing the Curve. USA, KPMG International. Retrieved from https:/home.kpmg.com/xx/en/home/insights/2015/03/global-construction-survey.html

Baker, B. N., Murphy, D. C., \& Fisher, D. (1988). Factors affecting project success. In Cleland, D.I., King, W.R. (Eds.). Project Management Handbook, 2nd ed., New York: VanNostrand Reinhold, 902-919

Barlow, G., Woolley, P., Rutherford, L. and Conradie, C. (2013). Project Management Survey Report. New Zealand, KPMG: 1 - 34.

Becerik-Gerber, B., Ku, K. H. and Jazizadeh, F. (2012). BIM-Enabled Virtual and Collaborative Construction Engineering and Management. Journal of Professional Issues in Engineering Education and Practice, 138(3), 234-245.

Belassi, W. and Tukel, O. I. (1996). A New Framework for Determining Critical Success/Failure Factors in Projects. International Journal of Project Management, 14(3), $141-151$.

Berkun, S. (2008). Making Things Happen: Mastering Project Management. O'Reilly.

Braun, M. S. P. (2015). Project and Programme Management Survey 2015. Sweden, KPMG: 32.

Brière, S., D. Proulx, Flores, O. N. and Laporte, M. (2015). Competencies of Project Managers in International NGOs: Perceptions of Practitioners. International Journal of Project Management, 33(1), 116-125.

Chandler, M. K. and L. R. Sayles (1971). Managing Large Systems. New York.

Cleland, D. I. and King, W. R. (1975). Systems Analysis and Project Management. New York: McGraw-Hill.

Construction Industry Development Board. (2014). Construction Industry Recorded RM92.3 billion of Worth of Projects. CIDB News, 22-23.

Davis, K. (2014). Different Stakeholder Groups and Their Perceptions of Project Success. International Journal of Project Management, $32(2), 189$ - 209.

Department of Statistics Malaysia. (2016). Gross Domestic Product Third Quarter 2016.

Gillard, S. (2009). Soft Skills and Technical Expertise of Effective Project Managers. Issues in Informing Science and Information Technology, 6, 723-729.

Hussin, J. M., Rahman, I. A., and Memon, A. H. (2013). The Way Forward in Sustainable Construction: Issues and Challenges. International Journal of Advances in Applied Sciences, 2(1), 15-24.

IPMA, I. P. M. A. (2006). ICB - IPMA Competence Baseline, Version 3.0. Netherlands, International Project Management Association: 1 - 213.

Jacobs, R. L. (2010). Training and Learning in the Workplace. International Encyclopedia of Education (Third Edition). P. P. B. McGaw. Oxford, Elsevier: 328-336. 
Jałocha, B., Krane, H. P., Ekambaram, A. and Prawelska-Skrzypek, G. (2014). Key Competences of Public Sector Project Managers. Procedia - Social and Behavioral Sciences, 119, 247-256.

Johns, R. (2010). Likert Items and Scales. Colchester: UK Data Archive. Survey Question Bank Methods Fact Sheet 1.

Kelley, K., Clark, B., Brown, B., and Sitzia, J. (2003). Good Practice in the Conduct and Reporting of Survey Research. International Journal for Quality in Health Care, 15(3): 261-266.

Kerzner, H. (2009). Project Management A Systems Approach To Planning, Scheduling And Controlling. USA, John Wilet \& Sons, Inc.

Khan, R. A., M. S. Liew and Ghazali, Z. B. (2014). Malaysian Construction Sector and Malaysia Vision 2020: Developed Nation Status. Procedia - Social and Behavioral Sciences, 109: 507-513.

Kwak, Y.-H. (2005). A Brief History of Project Management, Greenwood Publishing Group.

Mahmood, A. P. D. A., A. M. A. Hamidaddin and D. M. W. M. Shafiei (2006). What Competencies Do Project Managers Need? International Conference On Construction Industry (ICCI). Pendang, Indonesia.

Malik, M. E. and Danish, R. Q. (2010). Impact of Motivation to Learn and Job Attitudes on Organizational Learning Culture in a public service organization of Pakistan. Research Journal of South Asian Studies, 25(2), 217 - 235.

McHenry, R. L. (2008). Understanding the Project Manager Competencies in a Diversified Project Management Community Using a Project Management Competency Value Grid, Capella University.

Ministry of Finance. (2013). Bajet Kerajaan Persekutuan 2013. Ministry of Finance. Kuala Lumpur.

Ministry of Finance. (2014). Economic Report 2013/2014. Kuala Lumpur: 1-60.

Nguyen, L. D., S. O. Ogunlana and Lan, D. T. X. (2004). A Study on Project Success Factors in Large Construction Projects in Vietnam. Engineering Construction and Architectural Management, 11(6), $404-413$.

Olanrewaju, A. L. and A.-R. Abdul-Aziz (2015). An Overview of the Construction Industry. Building Maintenance Processes and Practices, Springer, 9-32.

Oxford (2016). Learning. English Oxford Living Dictionaries. Oxford University Press.

Pinto, J. K. and Selvin, D. P. (1987). Critical Factors in Successful Project Implementation. IEEE Transactions of Engineering Management, EM-34(1), 22 - 27.

Rockart, J. F. and Sloan, W. (1982). The Changing Role of the Information Systems Executive: A Critical Success Factors Perspective. Massachusetts Institute of Technology.

Santos, J. R. A. (1999). Cronbach's Alpha: A Tool for Assessing the Reliability of Scales. Journal of Extension, $37(2), 1-5$.

Sanvido, V., Grobler, F., Parfitt, K., Guvents, M., and Coyle, M. (1992). Critical Success Factors of Construction Projects. Journal of Construction Engineering and Management, 118(1), $94-111$.

Shivakumar, R. P. (2015). Project Management Overview. International Journal of Pharmaceutical Sciences and Business Management, 3(1), 1-4.

Singh, V. (2015). Project Management Origins \& Methodology Evolution in past 4,500 Years. Retrieved from https://www.linkedin.com/pulse/project-managementorigins-methodology-evolution-past-vikram-singh.

Steffens, K. (2015). "Competences, Learning Theories and MOOCs: Recent Developments In Lifelong Learning. European Journal of Education, $50(1)$, $41-59$.

Takey, S. M. and Carvalho, M. M. D. (2015). Competency Mapping in Project Management: An Action Research Study in an Engineering Company. International Journal of Project Management, 33(4), 784-796.

Tauber, T., T. Smolen and C. Probst (2016). How the Workforce Learns in 2016. Retrieved from http://get.degreed.com/how-the-workforce-learns-in-2016-report

Training Daily Advisor. (2016). Classroom Training: The Pros and the Cons. Training Daily Advisor, 1.

Training Daily Advisor. (2016). The Most Effective Training Techniques. 5.

Tsiga, Z., M. Emes and A. Smith (2016). Critical Success Factors For The Construction Industry. PM World Journal, V(VIII), 1-12.

Weaver, P. (2007). The Origins of Modern Project Management. Fourth annual PMI College of Scheduling Conference.

Yong, Y. C. and N. E. Mustaffa (2012). Analysis of Factors Critical to Construction Project Success in Malaysia. Engineering Construction and Architectural Management, 19(5): 543 - 556. 